\title{
Understanding the multiple voices of Islamic modernities: The case of Jihad ${ }^{1}$
}

\author{
DIETRICH JUNG \\ University of Southern Denmark
}

\begin{abstract}
In making a contribution to the debate on multiple modernities, this article addresses the growing fragmentation of contemporary interpretations of Islamic religious traditions. It argues that the polysemic nature of these interpretations mirrors to a certain extent the increasing functional differentiation of modern society. To substantiate this argument, the paper will first present a theoretical framework of global modernity that selectively draws on theories of multiple modernities, Modern Systems Theory, and of (post-)structuralist thinking. The empirical part of the paper takes the case of the Islamic institution of Jihad as its illustrative example. From a genealogical perspective, it analyses a number of steps of the (re-)interpretation of Islamic religious traditions from the classical period of pre-modern Islamic empires, via the Islamic reform movement of the nineteenth century, to the multiple voices of Islamic modernities in contemporary times.
\end{abstract}

Keywords: Multiple Modernities, Islamic Modernity, Islamic Reform, Jihad

In the introduction to a companion to contemporary Islamic thought the editor emphasised the increasing plurality in the interpretation of Islamic religious traditions with which we have been confronted in the intellectual production of Muslim thinkers since the nineteenth century (Abu-Rabi' 2006). In particular, the dissemination of modern print technologies and the spread of mass education has facilitated a significant break with the authoritative interpretation of Islamic sources by the religious learned (ulama), leading to a fragmentation of religious authority through new forms of social, religious, and political activism (Eickelman1992; Robinson

1 This article has benefited from a number of excellent comments. I would like to thank the two anonymous reviewers of Temenos, Martin Beck, Catherine Schwerin, Stephan Stetter, and the participants at a CRIC research seminar at Copenhagen University and the workshop 'Domains of Interpretation of Islamic Texts' at the Swedish Research Institute in Istanbul, where previous drafts of this article were discussed in April 2015. In addition, I am grateful to the Danish Council for Strategic Research, the Danish Council for Independent Research, and VELUX Foundation for supporting my research while this article was written. 
1993). Although there has never been a single, decisive religious authority in Islamic history, the modern situation is especially characterised by the degree and scope in which the very meaning and purposes of Islamic religious traditions have been contested (Mandaville 2007). These multiple voices of Islamic modernities have been documented and critically discussed in a burgeoning number of academic books that have also informed current public debates about the 'true nature of Islam' (Behloul, Leuenberger, and Tunger-Zanetti 2013; Cook and Lawrence 2005; Euben and Zaman 2009; Hunter 2009; Kamrava 2007; Kurzman 1998 and 2002).

Historically well-established schools of religious knowledge such as the famous al-Azhar in Egypt have been engaged in an uphill struggle with various kinds of modern Islamic activists and their polysemic interpretations of Islamic religious sources. While in the language of these activists general references to Islam appear almost obligatory, the ways in which Muslim thinkers, Islamist ideologues, Islamic civil society groups, politicians, and self-fashioned internet-Imams make these references to religion seem to be the result of free and sometimes methodologically unconsidered interpretation. In short, Muslim modernities have been characterised by a remarkable revival of references to Islam; however, these voices of Islam appear no longer to share common roots in the authoritative methods of interpretation of Islamic religious sources. How is this rise of multiple voices of Islamic modernities to be understood?

It is the purpose of this article to give a tentative answer to this question in three respects. In theoretical terms it will first sketch out a heuristic framework which is able to conceptually grasp the intrinsic relationship between unity and difference in modernity. In selectively drawing on elements of theories of multiple modernities, Modern Systems Theory, and elements of (post-) structuralist thinking, this theoretical framework aims at combining a generic theory of modernity with the empirical observation of its multiple forms. In this way the article aims to contribute to the ongoing debate about multiple modernities and the question of the relationship of this plurality with modernity as a generic concept. I argue that the polysemic nature of Islamic deliberations about modernity mirrors to a certain extent the increasing functional differentiation of modern society, in which social actors combine religious discourse freely with discursive elements from other spheres of society such as law, economics, politics, and education. What appears on the systemic level to be distinct discursive forms - that is to say, particular economic, political, religious, or legal communication - becomes a blurred patchwork of idiosyncratically constructed semantics at the level of social agency. 
Second, this article traces the historical origin of the currently observable fragmentation of the interpretation of Islamic traditions to the second half of the nineteenth century. In this period Islamic reformers established a discourse of modernity in which the linkage to Islam granted authenticity to new norms and institutions. They advocated the independent interpretation of the canonical sources of Islam, the Quran, and the prophetical traditions (sunna) as a means for the modernisation of Muslim societies and their liberation from the yoke of European colonialism. In doing so, the nineteenth century reform movement disembedded religious and juridical Islamic concepts from their traditional scholarly context, and assigned to them new and modern meanings (Aziz al-Azmeh 1996, 106-10). Certainly, the Islamic reform movement was not the only Muslim response to modernity. In the nineteenth and early twentieth centuries varieties of universalistic or nationalist ideas such as Turkism, Egyptianism, and Arab Nationalism competed with this religious imaginary of a specifically Islamic modernity. It was only in the course of the twentieth century that Islamic forms of modernity were able to assume a relative hegemony in the Muslim world. ${ }^{2}$

The Egyptian Sheikh Muhammad Abduh (1849-1905) was a paradigmatic figure in initiating this process of constructing specifically Islamic modernities. Abduh, himself a representative of the ulama and later Mufti of the Egyptian realm, propagated the right to independent reasoning (ijtihad) against the principle of the 'blind' imitation of a school of law (taqlid). With his polemic against taqlid Abduh aimed at liberating ijtihad from being the exclusive right of religious scholars who were following the established methods of religious interpretation of one of the four Sunni schools of law. Although independent religious reasoning had taken place throughout Islamic history (cf. Hallaq 1984), it became formally embedded in the methodological and interpretative traditions of specific schools of law. In their anti-clerically motivated critique of taqlid Abduh and his fellow reformers advocated a liberation of ijtihad from the confines of previous scholarly doctrines, and eventually paved the way for a development that facilitated the rise of the polysemic Islamic voices we can observe today (Jung 2011, 235-45).

Third, I choose the case of the Islamic institution of Jihad as a means of illustrating the theoretical and historical arguments mentioned above. In a dispute among Orientalist scholars during the First World War some of

2 As a result of continuing migration and digital technologies, the notion of the Muslim world has lost its territorial demarcation, while at the same time representing a transnational space of world society. 
the founding fathers of modern Islamic studies considered Jihad to be 'an atavist mediaeval Islamic doctrine', poised to disappear in modern times (Jung 2014, 5-7). In sharp contrast to this scholarly opinion, however, in the course of the twentieth century the Islamic institution of Jihad experienced not only an unexpected revival, but also a continuing extension of its meanings. With the rise in Islamist militancy these meanings of Jihad are now widely discussed. Jihad therefore represents an ideal case of general interest for illustrating the social process behind the modern fragmentation of the interpretation of Islamic religious concepts. ${ }^{3}$

The essay opens with a brief sketch of my heuristic framework of global modernity. In this first section I provide the reader with the theoretical perspective and the analytical tools that have guided my historical reconstruction in the article's subsequent sections of the rise of the multiple voices of Islamic modernities. This reconstruction, then, starts with a closer examination of the concept of Jihad in classical Islam and its formal legal institutionalisation in Islamic jurisprudence (figh). In this reconstruction the term 'classical Islam' refers to the long period of territorial expansion of premodern Islamic empires that accompanied the establishment of the four Sunni schools of law, roughly comprising the periods of Umayyad and Abbasid rule (661-1258). Against this historical background the third section addresses the transformation of Islamic concepts and institutions by the Islamic reform movement of the nineteenth century. As in the section on classical Islam, this third section also deals only with the mainstream in Sunni Islam, epitomised by paradigmatic historical reform figures such as Muhammad Abdu, Jamal al-Din al-Afghani (1838-97), and Rashid Rida (1865-1935). The article continues with a selective analysis of the various ways in which the concept of Jihad finds its application in the evolving polysemic environment of Islamic deliberations on modernity during the twentieth century. The focus in this section is on the adaption and reinterpretation of Jihad by Sunni Islamism as represented by enormously influential Islamist ideologues such as Hasan al-Banna (1906-49) and Sayyid Qutb (1906-66). I will end with brief conclusions regarding the possible consequences of these developments, and their significance for the debate about multiple modernities.

3 In choosing Jihad as an example, my aim is not to provide new knowledge about the conceptual history of this concept or the concept itself. Consequently, this article does not claim to make a new contribution to research on Jihad. 


\section{Global modernity and multiple modernities}

The theoretical hype of postmodernity has been replaced by a proliferating strand of literature on so-called multiple modernities. Originally, the late Shmuel Eisenstadt coined the concept of multiple modernities within the framework of civilisational theory. For him, modernity represented a distinct, cultural, political, and institutional programme that expanded throughout most of the world. The responses to the expansion of this programme of modernity have been manifested in the changing patterns of culturally and institutionally different forms of modernity (2001, 321-2). These multiple responses to modernity have been partly moulded by the legacy of the religious and/or imperial traditions of premodern civilisations (Arnason 2003). Taking their inspiration from Carl Jaspers' Axial Age Thesis (Jaspers 1956), Eisenstadt's and Arnason's theory of multiple modernities reintroduced religion to the scholarly discourse on modernity. They explained the rise of historically different forms of modernity with the impact of the cultural legacies of civilisational complexes such as Buddhism, Confucianism, Christianity, and Islam.

Being largely detached from Eisenstadt's and Arnason's theoretical premises of civilisational theory, the term 'multiple modernities' often merely serves as an expression for cultural diversity (Thomassen 2010, 338). The remaining common denominator of current proponents of modernities in the plural is their opposition to the previously hegemonic position of classical theories of modernisation from the 1950s and 1960s. In their efforts to bestow sociology with a scientific aura equal to the natural sciences (Eisenstadt 1991, 421), these theories perceived modernisation as a more or less linear historical process of the convergence of societies towards a single institutional, organisational, and cultural model. These probably overly simplistic academic representations of modernity have been deconstructed by postcolonial, postmodern, and poststructuralist theories. Yet modernity as a dominant category in the mind of academics and society at large has not disappeared. On the contrary, modernity has returned in multiple forms. By putting modernity into the plural, these new approaches express a mutual desire to overcome the notions of linearity, irreversibility, universalism, and Westernisation that characterises the classical modernisation theories (Lee 2013, 419). Yet the question remains as to whether there is any kind of generic concept left to which this conceptual multiplicity refers.

In tentatively answering this question, I take theories of social emergence as my point of departure (cf. Sawyer 2001, 2005). I suggest that global modernity should be understood as the emergence of two different levels of 
social reality. In sharp contradistinction to classical modernisation theories, this concept of modernisation is not defined by beginnings, nor does it imply the linearity of historical processes. Global modernity, instead, refers to an emerging level of social reality with new 'modern' properties. This approach liberates theories of modernity from the narrow and mechanical conceptualisation of post-Second World War sociology, without abandoning an understanding of modernisation in terms of sociocultural evolution. ${ }^{4}$ This is particularly important for the application of those concepts of classical sociology that represent the disciplinary tradition of understanding modernisation as social differentiation. In the work of classical sociologists, the rise of modern society was often defined by the increasing differentiation in functionally separate realms of social structures and social action. They identified modernisation with the emergence of relatively autonomous social institutions and practices such as the national state, capitalist economy, formal bodies of law, secular education, and formalised systems of scientific enquiry.

Modern Systems Theory has further stressed this emphasis of classical sociology on both functional differentiation as a core feature of modernity and its emerging character. In this strand of theory modernisation represents a form of sociocultural evolution in which functional differentiation replaces the primacy of segmentation and stratification in the social organisation of premodern orders (Luhmann 1981). At a highly abstract level Niklas Luhmann distinguished modern from premodern forms of social order on the basis of their dominant mode of social differentiation. Accordingly, he defined modernity in principle as an all-encompassing global system of communication based on functional differentiation. In Luhmann's theoretical perspective modern society is 'world society', and it is internally subdivided into relatively autonomous functional systems of communication such as economy, law, politics, science, and religion. In Luhmann's theoretical design these subsystems operate according to their own distinctive and self-referential communicative codes. ${ }^{5}$

While Luhmann defined modernity in its purely abstract dimension on the macro-level, the historically concrete institutional manifestations of the process of increasing functional differentiation and its reflection

4 To clarify: the kind of theory of sociocultural evolution I advocate here is not an evolutionist theory, according to which there is an unfolding logic or telos at work in human history.

5 Luhmann first presented this comprehensive sociological theory in Soziale Systeme. Grundriss einer allgemeinen Theorie (1987). 
in social agency have followed a multiplicity of varying social practices. Consequently, we must perceive modernisation as the advancement of functional differentiation enacted through the social practices of different 'cultural programmes'. To understand these cultural programmes, however, we have to shift our attention from the macro-level of Modern Systems Theory to a semantic level of reality, which 'comprises the intentionality of individual actors, their conscious beliefs and desires' (Viskovatoff 1999, 498). Thus, the simultaneity of unity and diversity of global modernity can be conceptualised through two different levels of reality: the systemic level of functional differentiation and the semantic level of human agency as a carrier of meaning. Applying the vocabulary of linguistics, Viskovatoff has suggested designating these levels as syntactic and semantic levels of reality which interpenetrate each other. Whereas the first level provides the rules and regularities of communication, the second attaches specific meanings to them (Viskovatoff 1999, 506-8).

Modern Systems Theory only articulates the syntactic level of reality, whereas civilisational theories suggest addressing the specific semantics of modernity by taking into account the cultural and institutional legacies of premodern civilisations, and therewith religions. On the surface we observe these combinations of two distinct levels of modernity as the puzzling and contradicting features of a globalisation process characterised by both homogenisation and fragmentation. Analytically, however, we can relate homogeneity and fragmentation to different levels of reality. Applying Eisenstadt's concept of multiple modernities, we can observe at the semantic level intertwined discourses of American, European, Islamic, and Asian modernities. However, in framing multiple modernities as the responses of different civilisational complexes to the challenges of modernity, Eisenstadt's approach is ill-suited to address the discursive variations within the civilisational complexes we can observe in the rise of the polysemic voices of Islamic modernities. How is this semantic complexity to be tackled?

An answer to this question may be found in the factual interpenetration of the syntactic and semantic levels. For analytical purposes, it makes sense to clearly distinguish these two levels of global modernity. On the one hand, there is the syntactic level of a 'cognitive deep structure' that provides fundamental rules and concepts as well as generating general themes of modernity. On the other, there is the level of culturally diverse semantics and social interactions through which social actors attach meaning to these general concepts and themes of modernity. Although empirically connected with each other, these two levels of social reality can be operationalised as 
two distinct levels of analysis. They do not, however, relate to each other hierarchically. Rather, they represent two different heuristic perspectives that make sense of a contradictory empirical whole. According to Michel Foucault's concept of epistemé (Foucault 1994), I define the syntactic level as the cognitive deep structure of modernity. I understand this 'archaeological' level as the 'unconscious' foundations of global bodies of knowledge (Foucault 1989). At this level we can observe the formative rules and discursive regularities of modernity which enable the mutual intelligibility of various modern semantics. This modern epistemé represents the most general form of our modern 'background knowledge' (Taylor 1991, 37), reflecting the functionally differentiated macro-structures of world society.

The syntactic level of global modernity provides common points of reference for the identification of objects of communication, such as state, economy, law, and religion. Moreover, at this level we can observe the generation of basic themes that take issue with the social transformations caused by the systemic imperatives of modern society. With regard to the role of religion, for instance, various semantic discourses about secularisation articulate general questions on issues such as the complex relationship between state and religion, the competition between revealed and scientific knowledge, the roles of individuals and communities, and the progressive separation of moralities from formal norms and laws. At the semantic level, then, we can observe a puzzling variety of modern vernaculars in which these typically modern questions become subjects of contentious societal negotiation. While the first level represents modernity in a generic sense, the second is the arena for the heterogeneous and often contradicting voices of multiple modernities. Here, social actors translate structural similarities into cultural diversity and establish relatively hegemonic cultural narratives by means of power. At this semantic level we find the historically and culturally varying voices of modernity characterised by a great variety of expressive, normative, and constitutive meanings. Here, social actors negotiate the aforementioned general themes in the shifting linguistic, symbolic, narrative, and moral contexts of their respective lifeworlds. It is at this level that we can discern the contestation among the different and often competing projects of modernity. These contestations, however, comprise variations between and within civilisational complexes. At this level civilisational traditions become subject to diverging discursive interpretations and cross-civilisational entanglements. Here, we can identify the ways in which discursive practices are accompanied and modified by direct personal encounters and the individual interpretations of historical events. 
In summary, my concept of global modernity has the quality of both an emerging social reality and an analytical device. On the one hand, global modernity represents the evolution of two distinct levels of the social with their own properties, while on the other, I employ these two levels as heuristic instruments in the observation of social processes. The analytical distinction between the syntactic and semantic levels of modernity allows me to conceive of the simultaneity of cultural homogenisation and fragmentation processes by associating these apparently contradictory processes of the global social reality with two different levels of analysis. In addition, this differentiation between two distinct levels of analysis enables a simultaneous application of structural theory and agency. It offers a combination of macro-sociological analyses with a micro-sociological focus on the social practices of particular collective and individual actors.

\section{The concept of Jihad in the premodern Islamic legal tradition}

In the classical period of the Islamic empires Jihad was first and foremost known as an institution of Islamic jurisprudence (figh). A good example is afforded by Bidayat al-Mujtahid, a legal handbook by the jurist and philosopher Ibn Rushd. Better known in Europe by his Latin name, Averroes, Ibn Rushd adhered to the Malikite school of law and lived in Andalusia (1126-98). One chapter of the first volume of his handbook is dedicated to the concept of Jihad. This chapter represents a juridical corpus on the justification, conditions, forms, and aims of warfare in Islamic law. Ibn Rushd discussed various opinions of the four Sunni schools of law (madhahib) about the legitimate use of physical force by Islamic rulers. In accordance with these schools, he defined Jihad as the collective responsibility to defend and/or extend the realm of Islamic rule. The political and religious authorities were allowed to proclaim Jihad as long as the conduct of war was subordinated to the jurisdiction of Islamic jurists (fuqaha) with respect to the adversaries as well as the means and forms of war's conduct. Generally speaking, Jihad was directed against non-Muslims; only those Muslims who were in open rebellion against legitimate Islamic rulers could become the target of Jihad (Ibn Rushd 1966, 390-418; see also: Peters 1977, 9-25). Consequently, in Islamic jurisprudence Jihad was a clearly and restrictively defined institution of 'justified war', closely knitted into the stratified authority structures of the classical Islamic empires.

From the theoretical perspective of Eisenstadt and Arnason, the above juridical concept of Jihad represents a historically specific combination of 
religious and imperial traditions that have characterised Islam as a premodern civilisational complex. This concept was the result of many centuries of intellectual deliberation among the religious learned and rulers. First, these deliberations took account of the fact that the Quran does not contain a clear doctrine of Jihad (Bonner 2006, 20). There is no doubt that the Quran has much to say about war, religious struggle, and military campaigns. However, this multiplicity of narratives related to violent strife is of a rather unsystematic character, and leaves us with a very inconsistent notion of Jihad (Firestone $1999,47)$. These inconsistencies regarding Jihad are linked in part to the broad range of semantic meanings from which the concept evolved. The verbal root jahada has many derivatives, by no means all of which have a religious connotation and only a few of which imply war or physical force. Generally speaking, the semantic field of the root jahada refers to meanings such as to take pains, to endeavour, to exert, to drudge, or to struggle. The most common denominator of these multiple meanings is a personal endeavour for a not precisely circumscribed purpose (Wehr 1985, 209). Second, the debates among religious specialists about the meaning of Jihad were also an expression of the historical contexts in which they emerged. This becomes particularly apparent in the sources of these deliberations, which predominantly refer to the large corpus of Islamic traditions, the so-called sunna of the Prophet, rather than to the Quran itself. This corpus of prophetic traditions evolved together with the expansion of the early Islamic empires during the first centuries after the death of the Prophet Muhammad. Together with the Quran, many of these traditions subsequently achieved the status of authoritative sources for Islamic jurisprudents. Ibn Rushd, for instance, based his elaborations on these sources and on the canon of syllogistic conclusions by previous scholars of religious law.

The discursive development of the concept of Jihad was further conditioned by particular historical circumstances. A good example is the differences between the conceptual meanings of Jihad according to the geographic location of their origins. In the frontier areas of the Islamic empires waging war to defend and extend territories apparently impacted the prevalent meaning of Jihad much more clearly than was the case in the pacified core territories of these empires. This emphasis on the military dimension of Jihad in frontier areas is documented in a specific corpus of traditions according to which the Prophet declared the defence of borders to be specifically rewarding in religious terms (Noth 1966, 66-87). In conclusion, the concept of Jihad evolved through centuries of methodologically guided deliberations among Islamic jurists. In Islamic jurisprudence Jihad predominantly 
represents a category defining the legitimate form of military campaigns in defence of and for the expansion of Islam; the concept revolves around 'the rules of killing at war' (El Fadl 1999).

However, this formal doctrine of Jihad by Islamic jurists certainly does not reflect all the social and religious practices amongst Muslims. Albrecht Noth points to this difference between formal legal doctrines and religious practices regarding Jihad in using the conceptual dichotomy of 'holy war' and 'holy struggle'. According to Noth, in early Islamic history we can already find personal forms of Jihad distinct from the juridical dogmas and authorised forms of warfare. This personal holy struggle could comprise both the military engagement of individual believers and the moral battle of pious Muslims with respect to religious virtues such as charity, fasting, and prayers (Noth 1966, 50). In reference to this dichotomy in meaning, Reuven Firestone argued against a quasi-evolutionary development of the concept of Jihad from a category of spiritual struggle for Islam to one of justified war. Instead, he suggested that in Islamic history a constant dualism of these meanings has been at work, a dualism Firestone assumed had its roots in the early Muslim community (Firestone 2006, 64).

Looking more closely at the intellectual history of Islam, we also find an influential concept of Jihad in Sufism, the 'mystical branch' of Islam, which is almost completely detached from the military connotations of the concept in figh. In Sufi reasoning Jihad is predominantly directed against human desires, and plays an important role in the justification of mystical practices (Noth 1960, 59; Sedgwick 2000, 18). Scholars have identified the period of the evolution of this spiritual concept of Jihad as being in the ninth century, which then in the twelfth century found its doctrinal manifestation in the teachings about the 'greater Jihad' by the jurist and theologian al-Ghazali (1058-111). According to al-Ghazali, the greater Jihad is a struggle concerning the moral self and the public good, whereas the 'little Jihad' refers to the military defence of Islam (Cook 2005, 35-7). However, these spiritual and moral forms of Jihad did not play a significant role in the Islamic legal tradition until the modern Islamic reform movement reinvented them in the nineteenth century.

\section{Modernity, authenticity, and Islamic traditions: Jihad in the thought of Islamic reform}

During the nineteenth century the Muslim world experienced a rise in Islamic reform movements that created an increasingly pervasive discourse 
of Islamic modernism. Three of the most prominent thinkers among these reformists were Jamal al-Din al-Afghani, Muhammad Abduh, and Rashid Rida, who became known in Western scholarship as the modernist Salafiyya movement (Hourani 1962). In the Ottoman Empire Namik Kemal (1840-88) and Ziya Gökalp (1876-1924) represent two leading reformist intellectuals, while in South Asia Sayyid Ahmed Khan (1817-98) and Muhammad Iqbal (1877-1938) were influential figures. In spite of regional and cultural differences, these modern Islamic thinkers shared a critical attitude towards the established class of the religious learned and their traditional dogmas. In order to liberate their countries from colonial rule, an important group of Muslim intellectuals called for a unity of religious and social reform. They publicly articulated the generic themes of modernity, such as the relationship between religion and science, the institution of the national state and the Islamic community (umma), secular and religious forms of education, and religious and legislative bodies of law. These Islamic reformers developed particular semantics of Islamic modernities based on the syntax of modernity. In the political context of colonial domination late nineteenth-century Islamic reformers interpreted Islamic traditions anew in light of the abovementioned general modern discursive themes, and with implicit reference to the advancement of functional differentiation (Jung 2011, 2015-248).

From the outset many of these nineteenth-century Muslim intellectuals aimed at becoming part of a universal civilisation as the European Enlightenment tradition had imagined it. Moreover, they appropriated elements of nineteenth-century scientific theory, such as historicism, evolutionism, and the philosophies of religious rationalisation. In Muhammad Abduh's thought, for instance, this appropriation of nineteenth-century discourse can be seen in Risalat al-Tawhid. This book compiles lectures which Abduh gave at the Sultaniyya in Beirut, a modern school founded in 1883 that emphasised the teachings of both religion and the modern sciences (cf. Sedgwick 2010). In these lectures Abduh adopted an evolutionary perspective of theories of religious rationalisation, describing the Quran as the first holy book in which 'revelation and reason merge through the voice of the messenger of God' (Abduh 1965, 8).

As Cemil Aydin has shown in his comparative study of the Middle East and Japan, it was only towards the beginning of the twentieth century that Muslim and Japanese thinkers gradually replaced this universalistic frame of reference with the concepts of distinct Islamic and Japanese civilisations that, at least in moral terms, were supposedly superior to the materialistic culture of the West. Aydin explains this shift from universalism to Islamic 
and Japanese particularism with reference to the asymmetric power relations of the international system as a consequence of the exclusionary politics of European colonialism and the rising nationalist ideologies in the formation of modern national states. In the context of international politics the previously cherished universalistic concept of civilisation gradually came to be associated with the colonial politics of Westernisation (Aydin 2007).

Taking their point of departure in the religious concept of the unity of God (tawhid), Islamic reformers now began to reconstruct Islam as a holistic civilisation, a form of cultural unity that represented the ideal of the totality of Islamic institutions and walks of life. The confusion of religious reform with international politics and modern state formation resulted in the idea of a specifically Islamic form of modernity, with its normative foundation in the revealed sources of the sharia. In this process the sharia, as revealed in the Quran and sunna, was gradually transformed into the central symbolic reference for the achievement of moral integrity, cultural authenticity, and national self-determination (cf. Dallal 2000, 347; Krämer 2010, 114). At the same time this sharia discourse was fused with modern legal communication and its foundation in the principle of positive law.

The nineteenth-century Islamic reformers proclaimed a return to the original sources of the revelation, without solely relying on the comprehensive interpretations in the huge legal corpuses of Islamic jurisprudence. One of their core arguments was that only independent reasoning with reference to pristine Islamic principles could provide an authentic platform for the building of a just and legitimate modern order. Consequently, the Islamic reform movement made the liberation of independent reasoning (ijtihad) from the institutional control of the ulama a core issue of religious reform. It was not the firmly established methods of figh, but a fresh reading of the Holy Scriptures with which they wanted to answer the social, political, and moral questions of modern times.

In the coercive straightjacket of imperialist power relations the religious language of Islam facilitated the propagation of modern ideas and institutions, without renouncing the specifically modern claim to authenticity. The discourse of Islamic reform constituted a fusion of Islamic religious concepts and narratives with the functionally differentiated conceptual language of modern economic, educational, legal, and political communication. In this way the discourse of Islamic modernity combined the syntactic rules of modernity with the cultural programme of the Islamic civilisational complex. It narrated the fundamental social transformation towards an increasingly functionally differentiated social life in an Islamic idiom. This 
specifically Islamic discourse of modernity generated a conceptual source for reflexive semantics, from which subsequent Muslim thinkers have selectively drawn. The conceptualisation of sharia in terms of positive law, the reinterpretation of shura as a form of representative government, the definition of zakat as an Islamic form of taxation, and the association of riba with capitalist interest-taking present but a few significant examples. With strong reference to the specifically modern mode of social differentiation, that is to say distinct realms of functionally differentiated communication, the Islamic reform movement bestowed new meanings on religious concepts. In this way modern Islamic reformers laid the foundations for the rise of the fragmented and polysemic nature of Islamic discourse that we see today.

In this process the institution of Jihad also attained new meanings. In his revolutionary efforts Jamal al-Din al-Afghani, for instance, applied the term to the mobilisation of Muslims against colonial rule. The Egyptian reformer Muhammad Abduh, who underpinned his call for reform with theological terminology, defined Jihad as the religiously motivated effort to work hard in everyday life for the revival of Muslim society (Ibrahim 1999, 71). For both Afghani and Abduh, Islam was synonymous with social activism, which they understood as a form of Jihad. They employed the premodern notion of 'holy struggle' as a new means of mobilising the population for their modernising projects. Taking up al-Ghazali's distinction, late nineteenth-century reformers interpreted the greater Jihad as a form of collective and individual striving for social reform, while assigning to the concept of the little Jihad a key role in the resistance against colonialism. Premodern anti-colonial movements in British India, North Africa, and the Sudan already perceived themselves as being in a Jihad against the colonial powers. However, their worldview had yet to encounter the nationalist impact that dominated the meaning of Jihad in the fight for independence later in the nineteenth century (Peters 1979). Together with the semantic variations of its linguistic roots, the semantic dualism in the meaning of Jihad provided the Islamic reform movement of the nineteenth century with religious templates for conceptual innovations, most significantly with templates for the justification of various forms of modern social activism in the fields of politics, economics, and education.

\section{The ideologisation of Islam and the polysemic nature of Jihad}

In November 1914 Sultan Mehmet V proclaimed the last 'official' Jihad in Islamic history. Based on a juridical opinion (fatwa) of the Sheikh al-Islam, the 
highest religious institution of the Ottoman Empire, the Sultan-Caliph called upon every Muslim to defend Islam against its enemies. These enemies of Islam were represented by the three European great powers: France, Great Britain, and Russia. In formal terms the proclamation of Jihad followed the rules of Islamic law. In content, however, it was a remarkable deviation, as this defence of Islam took place in the form of an alliance of the Ottoman Empire with the non-Muslim Empires of Germany and Austria. Even more striking, the initiative for this Jihad did not come from the Sublime Porte, but was a strategic move developed by the German foreign office in Berlin. Briefly, this Ottoman-German Jihad failed in every respect. Muslims under imperial control did not rally behind the cause of the Axis powers. On the contrary, the First World War saw many Muslims fighting against the Ottoman Empire under the flags of their respective colonial masters. The last officially declared Jihad ended in the defeat of the Ottoman Empire together with Germany and Austria, leading to the abolition of both the Sultanate (1922) and the Caliphate (1924) by Mustafa Kemal Atatürk. Since then the formal legal institutional framework for the proclamation of Jihad has not existed (Jung 2014, 5-8).

The abolition of the Caliphate, however, did not mean an end to the proclamation of Jihad. On the contrary, stripped of its institutional and interpretative constraints, the door was open for the flourishing of new applications of the term in a multiplicity of ways. The foundation of the Muslim Brotherhood by Hasan al-Banna in 1928 was a decisive turning point for this decoupling of Jihad from its institutional and interpretative rules. Generally speaking, Hasan al-Banna translated the Islamic discourse of modernity from elitist language into the vernacular of a religio-political movement. The Muslim Brotherhood was crucial in initiating a still ongoing process of the 'centrifugal ideologisation' of Islam. According to the sociologist Sinisa Malesevic, this process is 'a mass phenomenon that historically spreads from the centre of social organisations (or social movements, or both) to gradually encompass an ever wider population' (Malesevic 2010, 10). In so doing, the ideological activities of the elite and the broader masses of the population mutually reinforce each other, binding the ideological narrative at the macro-level to individual forms of solidarity at the microlevel $(2010,11)$.

This popularisation, societal dissemination, and trivialisation of the Islamic reform discourse by the Muslim Brotherhood movement was foundational in the evolution of the polysemic voices of Islam at the semantic level. The ideology of the Brotherhood was predicated on the idea of an 
Islamisation of modernity. In this process Jihad became a metaphor for social engagement fused with the organisational logic of a modern mass movement. In Banna's usage the term 'Jihad' represented an entire range of meanings, from militant resistance against British domination to the striving for social reform and the struggle for the moral betterment of individual Muslims. However, in contradistinction to the reformers of the late nineteenth century Banna placed new emphasis on the military character of Jihad. He firmly associated the little Jihad with notions such as violent struggle, death, and martyrdom (Mitchell 1969, 207). Hasan al-Banna further radicalised the idea of authenticity in his application of Islamic concepts, now aiming at the establishment of an authentic Islamic order without any borrowing from the normative and institutional achievements of Europe. At the same time the regulative claims of the Brotherhood were gradually expanded towards the imagination of a reorganisation of the functionally differentiating realms of economics, politics, law, education, arts, and religious practice under a form of Islamic governance (Commins 2005). From this paper's theoretical perspective, the idea of Islamic governance attained the role of giving the all-encompassing answer to the complexity of modern problems generated by increasing functional differentiation. The imposition of Islamic government on the diverging logics of different realms of society was thus translated into various forms of Jihad. In a process of centrifugal ideologisation the Islamisation of modern social realms such as education, economics, law, politics, and science became synonymous with a programme for the societal integration of an increasingly differentiated population.

In political terms Islamist ideologists further radicalised the notion of the little Jihad throughout the twentieth century. In particular, the work of Sayyid Qutb was instrumental in making it the core concept for revolutionary Islamist groups. Qutb, a member of the Egyptian branch of the Muslim Brotherhood, fundamentally revised three concepts of the Islamic tradition: justice (adala); the 'authority/sovereignty' of God (hakimiyya); and the pre-Islamic period of 'ignorance' (jahiliyya). In this revision the Islamic concept of adala was fused with the modern call to revolutionary social reforms in which an Islamic order represents a kind of third way between capitalism and socialism. Qutb linked this social dynamism to a political authority structure in which the absolute sovereignty of God, hakimiyya, was combined with a diagnosis of living in times of ignorance, jahiliyya. Qutb identified the increasing ethical differentiation of social realms with the polytheist jahiliyya, a modern form of ignorance, in which people have lost the one and only path of God. Qutb called for an existentialist Jihad 
against this modern jahiliyya, which he justified through the exemplary narratives about the life and struggles of the Prophet. His combination of adala, hakimiyya, jahiliyya, and jihad achieved a foundational role in the justification for a call to Islamist revolution. Numerous Islamist groups employed this thoroughly revised concept of the little Jihad in their militarisation of Qutb's existentialist political ideology. In declaring the modern world to be in a state of ignorance, Qutb's ideology justifies, in principle, a ubiquitous application of Jihad against everybody, circumventing all the institutional and normative constraints that once characterised Jihad in the legal tradition of Islamic jurisprudence. ${ }^{6}$

This autonomous logic of Jihad is at the heart of the thinking of militant Islamists such as Abdallah Azzam, who recruited Arab volunteers for the war in Afghanistan. Azzam vehemently turned against apologetic attempts to downplay the military dimension of Jihad. Moreover, he considered Jihad to be the individual duty of every Muslim, not a collective duty for the defence of Islam. According to Azzam, all Muslims were individually obliged to wage Jihad as long as there was any Islamic territory under siege (McGregor 2003; Hegghammer 2010/11, 74-7). Osama bin Laden and alQaida further radicalised this position. In their theory of global Jihad the obligation to wage war was stripped of its territorial confines. In the worldview of contemporary jihadist organisations Muslims have to constantly defend Islam against internal and external enemies across all boundaries. In this almost apocalyptic character of Jihad references to Islamic religious traditions have meanwhile become a means of legitimising all kinds of militant fantasies.

Parallel to this unleashing of the little Jihad from all its institutional and normative constraints, we can observe the relatively arbitrary application of the concept of greater Jihad for individual and collective struggles in every walk of life. The Malay author Azly Rahman, for instance, has lamented a culture of public discourse in his country in which people are 'urging this or that kind of jihad at times for reasons unknown' (Rahman 2015, 33). Lara Deeb described forms of public piety and community work among her female interlocutors in the Shiite quarter of al-Dahiyya in Beirut as a specific kind of women's Jihad (Deeb 2006). In fighting their Jihad, these women were 'engaged in defining, reinforcing, and prioritizing certain religious discourses and practices over others, constantly distancing themselves from those considered traditional' $(2006,128)$. In an anthology concerned with

6 The Islamist ideology of Sayyid Qutb has been the topic of numerous studies; in this part I refer to the works of Shepard (1996), Musallam (2005), and Khatab (2006). 
non-violent movements of civil unrest in the Middle East Maria Stephan has placed various forms of civic striving under the rubric of a 'civilian jihad', a term that she derives from the Iraqi intellectual Khalid Kishtainy (Stephan 2009). Meanwhile, Tariq Ramadan calls European Muslims to fight a Jihad for trust. According to Ramadan, this 'genuine' Jihad for trust aims at achieving 'self-respect and respect for others: for everyone, Muslim and non-Muslims' (Ramadan 2010, 114). In a very recent scholarly article, to name a final example, the author aims to explicate 'the possibility of retrieving at the very least the spirit, if not the term, of jihad for the purposes of peacebuilding' (Sheikh 2015, 289). In an apologetic vein Muslims redefine Jihad in multiple ways 'to reclaim the concept of "Jihad" and to invest it with other meanings different to those imposed by the Mullahs and militants' (Noor 2001).

These examples show the various ways in which contemporary Muslim thinkers fuse religious discourse freely with elements of political, economic, scientific, educational, or artistic communication. They refer to Islamic religious sources in order to construct the various semantics of 'authentic' Islamic modernities. However, in this process the interpretation of the Islamic religious tradition has not only lost its authoritative methodological foundations, but increasingly represents a field of highly contested meanings. The concrete meanings of Islamic concepts, norms, and institutions, and with them their role as signifiers for specific forms of Islamic modernities, have become polysemic.

\section{Conclusions}

This article has sketched a theoretical framework for understanding the multiple voices of Islamic modernities as a plurality of modern Islamic semantics, based on a general syntax of modernity. In taking the case of Jihad as its example, the article has attempted to demonstrate how the interpretation of Islamic religious institutions has developed in a highly contested field of social negotiations, making it subject to continuous processes of reconstruction and reinterpretation. Certainly, the meaning of religious traditions was also contingent on non-religious influences in premodern times. The inconsistencies of the Quran and the semantic breadth of some of its terms have continuously invoked the necessity of interpretation. However, this article has argued that, beginning with the modern Islamic reform movement of the nineteenth century, this interpretation of Islamic religious traditions has increasingly liberated itself from the relative hermeneutic monopolies of the 
religious learned. The increasingly functional differentiation of the social has not only undermined premodern structures of interpretative authority, but has also provided a radically new and openly accessible syntax for a more independent and thus free interpretation of Islamic religious sources.

Analysing contemporary discourses of Islamic modernities at the semantic level, we can observe competing structures of meaning within Islam and in the interaction of Muslims with the non-Islamic world. It is on this semantic level of reality that the polysemic and fragmented readings of Islamic texts take place. To understand the evolution and inner logic of these conflicts about meaning, however, it is important to take into account the syntactic level of the cognitive deep structure of modernity. Here, the article suggests that a generic concept of modernity based on theories of functional differentiation can help us to understand the evolution of the cultural idiosyncrasies that we observe at the semantic level. Therefore, in combining perspectives from different strands of social theory, the two-level model of an emerging global modernity proposed here can help make sense of the polysemic readings of Islamic and other traditions as we experience them today.

In light of the theoretical approach presented here, modernisation appears as the conflict-prone reorganisation of social life under the 'specific systemic modern property' of functional differentiation. In the Islamic discourse of modernity this reorganisation has been articulated and justified through the discursive integration of the logics of politics, economics, law, and science in the conceptual language of Islam. This process is intrinsic to the evolution of global modernity as it finds its historical expression in the intellectual shift towards an Islamisation of the social. In this article I have chosen the case of Jihad as an illustration of this process; Islamic concepts such as adala, sharia, umma, and tawhid would provide other examples for this modern combination of religious with other forms of communication. In the course of the twentieth century this way of constructing 'authentic' forms of modernity with strong references to Islam has attained relative hegemony in the Muslim world. This hegemony of references to religion in the construction of Muslim modernities is characterised by the multiplicity of ways in which Muslims read the canonical texts of Islam. Islamic traditions are not applied as an undisputed and coherent cultural programme, as Eisenstadt's theory might suggest. Rather, the religious and imperial traditions of the civilisational complex of Islam serve as a reservoir of more or less authoritative concepts, symbols, and practices in a competitive process of the formation of modern social imaginaries among Muslim thinkers and 
activists. The distinction between syntactic and semantic levels of modernity provides an analytical prism for an understanding of the multiple ways in which these social actors combine generic elements of modernity with culturally particular forms in constructing multiple modernities within a civilisational complex.

In the absence of mutually accepted authoritative institutions of religious interpretation the only common point of reference in these hermeneutical processes is the mere idea of the necessity to bestow the legitimacy of Islamic authenticity on the competing forms of modernity. Since its invention in the latter part of the nineteenth century, Muslim intellectuals, social movements, and state authorities have spread this discourse of an authentic-cum-Islamic modernity throughout the twentieth century. As long as this idea of modern Islamic authenticity exerts relative discursive hegemony over Muslim deliberations of modernity, this kind of Islamisation of the Muslim world will continue. However, infusing religious concepts continuously with elements of the logic of economic, educational, legal, or political communication eventually carries the risk of depriving them of their religious content.

DIETRICH JUNG is Professor of Contemporary Middle East Studies at the Department of History, University of Southern Denmark. E-mail: jung@sdu.dk

References

Abduh, Muhammad

1965 Risalat al-Tawhid. Cairo.

Abu-Rabi', Ibrahim M.

2006 Editor's Introduction. - Abu-Rabi' I. M. (ed.), The Blackwell Companion to Contemporary Islamic Thought, 1-20. Oxford: Blackwell.

Arnason, Johan

2003 Civilizations in Dispute. Leiden: Brill.

\section{Aydin, Cemil}

2007 The Politics of Anti-Westernism in Asia. Vision of World Order in PanIslamic and Pan-Asian Thought. New York: Columbia University Press. 
Al-Azmeh, Aziz
1996 Islams and Modernities. Second Edition. London: Verso.

Behloul, Samuel M. \& Susanne Leuenberger \& Andreas Tunger-Zanetti (eds)

2013 Debating Islam: Negotiating Religion, Europe, and the Self. Bielefeld: transcript.

Bonner, Michael

2006 Jihad in Islamic History. Doctrines and Practice. Princeton and Oxford: Princeton University Press.

Commins, David

2005 Hasan al-Banna (1906-1949). - Rahnema Ali (ed.), Pioneers of Islamic Revival, 125-53. London: Zed books.

Cook, David

2005 Understanding Jihad. Berkeley: University of California Press.

Cooke, Miriam \& Bruce Lawrence (eds.)

2005 Muslim Networks from hajj to hip hop. Chapel Hill: University of North Carolina Press.

Dallal, Ahmed

2000 Appropriating the Past: Twentieth-Century Reconstruction of PreModern Islamic Thought. Islamic Law and Society 7 (1), 325-58.

Deeb, Lara

2006 An Enchanted Modern. Gender and Public Piety in Shi'i Lebanon. Princeton: Princeton University Press.

Eickelman, Dale F.

1992 Mass Higher Education and the Religious Imagination in Contemporary Arab Societies. American Anthropologist 19 (4), 643-55.

\section{Eisenstadt, Shmuel N.}

1992 A Reappraisal of Theories of Social Change and Modernization. Haferkamp H and Smelser NJ (eds.), Social Change and Modernity, 412-31. Berkeley: University of California Press.

2000 Multiple Modernities. Daedalus 129 (1), 1-29.

2001 The Civilizational Dimension of Modernity: Modernity as a Distinct Civilization. International Sociology 16 (3), 320-40.

El Fadl, Khaled Abou

1999 The Rules of Killing at War: An Inquiry into Classical Sources. The Muslim World LXXXIX (2), 144-57.

Euben, Roxanne L. \& Muhammad Qasim Zaman (eds.)

2009 Princeton Readings in Islamist Thought. Texts and Contexts from al-Banna to Bin Laden. Princeton: Princeton University Press. 


\section{Firestone, Reuven}

1999 JIHAD. The Origin of Holy War in Islam. Oxford: Oxford University Press.

\section{Foucault, Michel}

1989 Archaeology of Knowledge. London and New York: Routledge.

1994 The Order of Things. London and New York: Routledge.

Hallaq, Wael B.

1984 Was the Gate of Ijtihad Closed? International Journal of Middle East Studies 16 (1), 3-41.

\section{Hegghammer, Thomas}

2010/11 The Rise of Muslim Foreign Fighters: Islam and the Globalization of Jihad. International Security 35 (3), 53-94.

\section{Hourani, Albert}

1962 Arabic Thought in the Liberal Age 1798-1939, reissued with a new preface 1983. Cambridge: Cambridge University Press.

\section{Hunter, Shireen}

2009 Reformist Voices of Islam: Mediating Islam and Modernity. Armonk and London: M.E. Sharpe.

\section{Ibn Rushd, Muhammad A.}

1966 Bidayat al-Mujtahid wa Nihayat al-Muqtasad. Vol. I. Maktaba al-Kuliyyat al-Azhariyye: Cairo.

\section{Ibrahim, Haslina}

1999 Free Will and Predestination: A Comparative Study of the Views of Abu al-Assan Al-Ash'ari and Muhammad 'Abduh. Unpublished MA thesis, Kulliya of Islamic Revealed Knowledge and Human Sciences. Kuala Lumpur: International University Malaysia.

\section{Jaspers, Karl}

1956 Vom Ursprung und Ziel der Geschichte. Frankfurt a.M. and Hamburg: Fischer.

\section{Jung, Dietrich}

2011 Orientalists, Islamists and the Global Public Sphere. A Genealogy of the Modern Essentialist Image of Islam. Sheffield: Equinox.

2014 The 'Ottoman-German Jihad': Lessons for the Contemporary 'Area Studies' Controversy. British Journal of Middle Eastern Studies 41(1), 1-19.

\section{Kamrava, Mehran}

2007 New Voices of Islam: Rethinking Politics and Modernity-A Reader. Berkeley and Los Angeles: University of California Press. 


\section{Khatab, Sayed}

2006 The Power of Sovereignty. The Political and Ideological Philosophy of Sayyid Qutb. London and New York: Routledge.

\section{Krämer, Gudrun}

2010 Hasan al-Banna. Oxford: One World Publications.

\section{Kurzman, Charles (ed.)}

1998 Liberal Islam: A Source Book. Oxford: Oxford University Press.

2002 Modernist Islam, 1840-1940: A Sourcebook. Oxford: Oxford University Press.

Lee, Raymond M.

2013 Modernity, Modernities and Modernization: Tradition Reappraised. Social Science Information 52 (3), 409-24.

\section{Luhmann, Niklas}

1981 Geschichte als Prozess und die Theorie sozio-kultureller Evolution. In Soziologische Aufklärung, Band 3. Opladen: Westdeutscher Verlag.

1987 Soziale Systeme. Grundriss einer allgemeinen Theorie. Frankfurt a.M.: Suhrkamp Verlag.

\section{Malesevic, Sinisa}

2010 The Sociology of War and Violence. Cambridge: Cambridge University Press.

\section{McGregor, Andrew}

2003 'Jihad and the Rifle Alone': Abdullah Azzam and the Islamist Revolution. The Journal of Conflict Studies 22 (2), 92-113.

\section{Mitchell, Richard P.}

1969 The Society of the Muslim Brothers. London: Oxford University Press.

\section{Musallam, Adnan A}

2005 From Secularism to Jihad. Sayyid Qutb and the Foundations of Radical Islam. Westport and London: Praeger.

\section{Noor, Farish A.}

2001 The Evolution of 'Jihad' in Islamist Political Discourse: How a Plastic Concept Became Harder. Social Science Research Council, www.ssrc. org/sept11/essays/noor.htm.

\section{Noth, Albrecht}

1966 Heiliger Krieg und heiliger Kampf in Islam und Christentum. Beiträge zur Vorgeschichte und Geschichte der Kreuzzüge. Bonn: Ludwig Rohrscheid Verlag. 


\section{Peters, Rudolph}

1977 Jihad in Mediaeval and Modern Islam. Leiden: Brill.

1979 Islam and Colonialism. The Doctrine of Jihad in Modern History. The Hague, Paris and New York: Mouton.

\section{Rahman, Azly}

2015 Controlled Chaos. Essays on Malaysia's New Politics Beyond Mahathirism and the Multimedia Super Corridor. Petaling Jaya: Strategic Information and Research Development Centre.

\section{Ramadan, Tariq}

2010 What I Believe. Oxford: Oxford University Press.

\section{Robinson, Francis}

1993 Technology and Religious Change: Islam and the Impact of Print. Modern Asian Studies 27 (1), 229-51.

Sawyer, Keith R.

2001 Emergence in Sociology: Contemporary Philosophy of Mind and Some Implications for Sociological Theory. American Journal of Sociology 107 (3), 551-85.

2005 Social Emergence. Societies as Complex Systems. Cambridge: Cambridge University Press.

\section{Sedgwick, Mark}

2000 Sufism: The Essentials. Cairo: American University of Cairo Press.

2010 Muhammad Abduh. Oxford: Oneworld Publications.

\section{Sheikh, Naveed S.}

2015 Reclaiming Jihad as a Strategy of Conflict Transformation. Peace Review 27 (3), 288-95.

\section{Shepard William E.}

1996 Sayyid Qutb and Islamic activism. A translation and critical analysis of Social Justice in Islam. Leiden: Brill.

\section{Stephan, Maria S.}

2009 Civilian Jihad. Non-Violent Struggle, Democratization, and Governance in the Middle East. London and New York: Palgrave.

\section{Thomassen, Bjørn}

2010 Anthropology, Multiple Modernities and the Axial Age Debate. Anthropological Theory 10 (4), 321-42.

\section{Taylor, Charles}

1991 The Ethics of Authenticity. Cambridge, MA: The Belknap Press of Harvard University Press. 


\section{Viskovatoff, Alex}

1999 Foundations of Niklas Luhmann's Theory of Social Systems, Philosophy of the Social Science 29 (4), 481-516.

\section{Wehr, Hans}

1985 Arabisches Wörterbuch für die Schriftsprache der Gegenwart. 5th Edition. Wiesbaden: Harrassowitz. 
